\title{
Response of Dicamba-Resistant Soybean to Glyphosate/Dicamba Application Rate and Timing
}

\author{
Nader Soltani*, Lynette Brown, Peter H. Sikkema \\ University of Guelph, Ridgetown Campus, Ridgetown, Canada \\ Email: *soltanin@uoguelph.ca
}

How to cite this paper: Soltani, N., Brown, L. and Sikkema, P.H. (2019) Response of Dicamba-Resistant Soybean to Glyphosate/ Dicamba Application Rate and Timing. American Journal of Plant Sciences, 10, 1022-1029.

https://doi.org/10.4236/ajps.2019.106074

Received: May 25, 2019

Accepted: June 22, 2019

Published: June 25, 2019

Copyright $\odot 2019$ by author(s) and Scientific Research Publishing Inc. This work is licensed under the Creative Commons Attribution International License (CC BY 4.0).

http://creativecommons.org/licenses/by/4.0/

\begin{abstract}
Three field experiments were conducted during 2016 and 2017 in southwestern Ontario, Canada to evaluate the effect of glyphosate/dicamba (2:1 ratio) applied at the V2/V3 or V4/V5 growth stage on dicamba-resistant (DR) soybean injury, growth response and yield. At $1 \mathrm{DAA}$, glyphosate/dicamba at 450, 900, 1350, 1800 and 3600 g.ae.ha ${ }^{-1}$ caused $0,0.3,1.8,3.3$ and $5.8 \%$ growth response (leaf droop) when applied at the V2/V3 growth stage and $0.3 \%$, $1.3 \%, 1.5 \%, 2.3 \%$ and $4.5 \%$ growth response when applied at V4/V5 growth stage in DR soybean, respectively. The growth response was similar at 3 DAA. This response was transient with no growth response observed at $7 \mathrm{DAA}, 2$ $\mathrm{WAB}, 4 \mathrm{WAB}, 8 \mathrm{WAB}$, and late Sept. (R8 growth stage). Glyphosate/dicamba at $450,900,1350,1800$ and $3600 \mathrm{~g} \cdot \mathrm{ae} \cdot \mathrm{ha}^{-1}$ caused $0.0,1.4 \%, 3.6 \%, 5.7 \%$ and $10.7 \%$ injury (speckled chlorosis and necrosis and leaf distortion) when applied at the V2/V3 growth stage and $0.5 \%, 0.7 \%, 2.0 \%, 3.7 \%$ and $6.9 \%$ injury when applied at the V4/V5 growth stage in DR soybean, respectively. The injury observed was transient with no injury observed at 4 and $8 \mathrm{WAB}$ and late Sept. (R8). There was no impact of glyphosate/dicamba at various rates evaluated on maturity and seed yield except at $1350 \mathrm{~g} \cdot \mathrm{ae} \cdot \mathrm{ha}^{-1}(\mathrm{~V} 2 / \mathrm{V} 3)$ and 3600 $\mathrm{g} \cdot \mathrm{ae} \cdot \mathrm{ha}^{-1}(\mathrm{~V} 4 / \mathrm{V} 5)$ which caused a $6 \%$ reduction in yield of DR soybean yield compared to the weed-free control. Based on these results, glyphosate/dicamba at the labelled rates can be safely applied at the V2/V3 and V4/V5 growth stage in DR soybean. However, care is needed to avoid spray overlaps as the $2 \times$ rate can result in significant crop injury and yield reduction in DR soybean.
\end{abstract}

\section{Keywords}

Chlorosis, Leaf Distortion, Leaf Droop, Necrosis, Seed Yield, Glycine max 


\section{Introduction}

Soybean [Glycine $\max$ (L.) Merr.] is the most popular grain legume grown in Ontario and contributes significantly to the total value of agriculture sector in the province [1]. In 2018, approximately 4.2 million tonnes of soybean were produced from 1.22 million ha in Ontario with a farm-gate value of nearly $\$ 1.7$ billion [1]. Controlling weeds, especially herbicide-resistant biotypes, is one of the most important concerns for soybean growers in Ontario. Currently, the problematic glyphosate-resistant (GR) weeds in the province include Conyza canadensis (L.) Cronq. (Canada fleabane), Amaranthus rudis (waterhemp), Ambrosia trifida L. (giant ragweed) and Ambrosia artemisiifolia L. (common ragweed). Concerns about herbicide-resistant weeds, especially GR biotypes, have prompted agricultural companies to develop dicamba-resistant (DR) soybean with genetic traits that confer resistance to dicamba and glyphosate [2].

Dicamba is a benzoic acid herbicide that controls nearly 100 broad-leaved annual weeds [3]. Additionally, dicamba has been reported to suppress more than 100 perennial broadleaved weed species including woody species [4]. Globally, there are only six dicamba-resistant weed species [5]. Research has shown that dicamba applied postemergence at the appropriate application timing, alone or in combination with other herbicides, can provide excellent control of troublesome broadleaved weeds including GR biotypes in soybean [2] [6] [7] [8] [9] [10]. Glyphosate/dicamba mixture used with DR soybean will allow glyphosate to be used in combination with another active ingredient with a different site-of-action to control troublesome weed species including GR biotypes and can be one component of a diversified integrated weed management program [11].

Glyphosate/dicamba use along with DR soybean has become popular in recent years among soybean producers in North America. Growers in the United States seeded nearly 10 million hectares of DR soybeans in 2017 [12]. Similarly, soybean growers in eastern Canada seeded 13 and $31 \%$ of their total production with DR soybean cultivars in 2017 and 2018, respectively.

Glyphosate/dicamba is currently registered at 900 (600 g.ae $\cdot \mathrm{ha}^{-1}$ of glyphosate $+300 \mathrm{~g} \cdot \mathrm{ae} \cdot \mathrm{ha}^{-1}$ of dicamba premixed) to 1800 (1200 g.ae $\cdot \mathrm{ha}^{-1}$ of glyphosate +600 g.ae $h a^{-1}$ of dicamba premixed) g.ae $\cdot \mathrm{ha}^{-1}$ for use in DR soybean in Ontario. DR soybean has been commercially available since 2016, but there has been little published information on the sensitivity of DR soybean cultivars to glyphosate/ dicamba, especially at the $0.5 \times$ and $2 \times$ rates when applied at different application timings under Ontario environmental conditions. In non-DR crops, dicamba like other auxinic herbicides generally causes leaf cupping and crinkling, stem and petiole curling and twisting, and interference with phloem sucrose and nutrient transport which can result in chlorosis, wilting, stunting and total necrosis of the crop [6] [13] [14].

The purpose of this study was to determine the effect of glyphosate/dicamba $\left(450,900,1350,1800\right.$ and $\left.3600 \mathrm{~g} \cdot \mathrm{ae} \cdot \mathrm{ha}^{-1}\right)$ applied postemergence at the V2/V3 
(POST 1) or V4/V5 (POST 2) growth stages on DR soybean growth response, injury, maturity and yield.

\section{Material and Methods}

\subsection{Study Establishment}

There were three field experiments conducted during 2016 and 2017 at the University of Guelph Ridgetown Campus (GPS: 42.454011, -81.879970) near Ridgetown, ON, Canada. The soil was a loam with $47 \%$ sand, $37 \%$ silt, $16 \%$ clay, $5.1 \%$ organic matter and $\mathrm{pH}$ of 6.3 in 2016 at site A; loam with $40 \%$ sand, 34\% silt, $26 \%$ clay, $3.9 \%$ organic matter and $\mathrm{pH}$ of 7.6 in 2016 at site $\mathrm{B}$; and loam with $43 \%$ sand, $42 \%$ silt, $15 \%$ clay, $4.2 \%$ organic matter and pH of 6.5 in 2017 . Seedbed preparation consisted of fall moldboard plowing followed by two passes with a field cultivator with rolling basket harrows in the spring.

The experiments were arranged in a randomized block design with four replications. Treatments included a weed-free control, and glyphosate/dicamba at 450, 900, 1350, 1800 and $3600 \mathrm{~g} \cdot \mathrm{ae}^{\mathrm{h}} \mathrm{ha}^{-1}$ applied postemergence (POST) at the $\mathrm{V} 2 / \mathrm{V} 3$ and V4/V5 soybean growth stages. Plots were $3 \mathrm{~m}$ wide (4 soybean rows spaced $75 \mathrm{~cm}$ apart) and $8 \mathrm{~m}$ long. DR soybean (DKB 14-41) was planted at the rate of 370,000 seed $\mathrm{ha}^{-1}$ in mid to late-May of each year. Herbicides were applied postemergence at the V1/V2 (POST 1) and V4/V5 (POST 2) growth stages when soybean was up to $17 \mathrm{~cm}$ and 35 tall, respectively. Herbicides were applied with a $\mathrm{CO}_{2}$-pressurized backpack sprayer calibrated to deliver $200 \mathrm{~L} \mathrm{ha}^{-1}$ aqueous solution at $207 \mathrm{kPa}$ using 4 ULD 120-02 nozzles (TeeJet ${ }^{\circledR}$ Ultra low-drift 12002 nozzles, Spraying Systems Company, P.O. Box 7900 Wheaton, IL 60189$7900)$ spaced $50 \mathrm{~cm}$ apart. The experimental area was maintained weed-free during the entire growing season.

\subsection{Data Collection}

Percent growth response (leaf droop) was evaluated based on a scale of $0 \%$ to $100 \%$ ( 0 was no leaf droop and 100 was total leaf droop) at 1, 3 and 7 days after application (DAA); 2, 4 and 8 weeks after POST 2 application (WAB); and late Sept. (R8 growth stage). Percent DR soybean injury (speckled chlorosis and necrosis and leaf distortion) was also evaluated using the same scale (0 was no visible injury and 100 was total soybean necrosis) at 1, 3 and 7 DAA; 2, 4 and 8 WAB; and late Sept. (R8). When soybean reached maturity in October of each year, soybean seed yield was determined by harvesting the middle 2 rows of each plot with an ALMACO ${ }^{\mathrm{mm}}$ small plot combine ALMACO $^{\mathrm{m}}$, $99 \mathrm{M}^{\mathrm{M}}$ Avenue, Nevada, Iowa 50201-1558 USA). Seed yield was adjusted to $13.0 \%$ seed moisture content.

\subsection{Statistical Analysis}

Data were analyzed using the GLIMMIX procedure in SAS (Ver. 9.4, SAS Institute Inc., Cary, NC). The treatments were arranged in a randomized complete 
block design replicated 4 times. The fixed effect was herbicide treatment and random effects were year-location combinations (environment), replicate within the environment and the environment by treatment interaction. The best distribution and associated link function for each parameter was chosen by comparing fit statistics, residual plots and the Shapiro-Wilk statistic among the potential distributions. Least square means (LSMEANS) were calculated on the data scale by using the inverse link function, and pairwise comparisons were subjected to Tukey's adjustment before determining treatment differences at $\mathrm{P}<$ 0.05 . The weed-free control was assigned a value of 0 for percent growth response and percent injury due to zero variance. Comparisons were still possible between the other treatments and the value zero using the LSMEANS output and differences were identified. The Gaussian distribution and identity link were used for percent growth response, percent injury 1, 3 and 7 DAA; 4 and 8 WAB; and late Sept. (R8), moisture and yield. The normal distribution (identity link) with an arcsine square root transformation was used for percent injury $2 \mathrm{WAB}$ and the data was back-transformed for the presentation of results.

\section{Results and Discussion}

Growth response at $7 \mathrm{DAA}, 2 \mathrm{WAB}, 4 \mathrm{WAB}, 8 \mathrm{WAB}$, and late Sept. (R8) was zero across all locations and years and therefore the date is not presented. Similarly, percent soybean injury at $1 \mathrm{DAA}, 4 \mathrm{WAB}, 8 \mathrm{WAB}$, and late Sept. (R8) was zero across all locations and years and therefore is not presented.

\subsection{Growth Response (Leaf Droop)}

At 1 DAA, glyphosate/dicamba applied at 450, 900, 1350, 1800 and 3600 g.ae.ha ${ }^{-1}$ to V2/V3 DR soybean caused $0.0 \%, 0.3 \%, 1.8 \%, 3.3 \%$ and $5.8 \%$ growth response, respectively (Table 1 ). At 3 DAA glyphosate/dicamba applied at 450,

Table 1. Percent growth response, injury, moisture at maturity and yield of dicamba-resistant soybean (Ridgetown 2016-2017) treated with glyphosate/dicamba at various rates at two POST timings. Means followed by a different letter within a column are significantly different according to a Tukey-Kramer multiple range test at $\mathrm{P}<0.05^{\mathrm{a}}$.

\begin{tabular}{|c|c|c|c|c|c|c|c|c|c|}
\hline \multirow{2}{*}{ Treatment } & \multirow{2}{*}{$\begin{array}{c}\text { Rate } \\
\left(\mathrm{g} \cdot \mathrm{ai} \cdot \mathrm{ha}^{-1}\right)\end{array}$} & \multirow{2}{*}{$\begin{array}{l}\text { Application } \\
\text { Timing }\end{array}$} & \multicolumn{2}{|c|}{ Growth Response (\%) } & \multicolumn{3}{|c|}{ Injury (\%) } & \multirow{2}{*}{$\begin{array}{c}\text { Moisture } \\
(\%)\end{array}$} & \multirow{2}{*}{$\begin{array}{c}\text { Yield } \\
\left(\mathrm{T} \cdot \mathrm{ha}^{-1}\right)\end{array}$} \\
\hline & & & $1 \mathrm{DAA}$ & $3 \mathrm{DAA}$ & $3 \mathrm{DAA}$ & $7 \mathrm{DAA}$ & $14 \mathrm{DAB}$ & & \\
\hline Weed-free control & & & $0.0 \mathrm{a}$ & $0.0 \mathrm{a}$ & $0.0 \mathrm{a}$ & $0.0 \mathrm{a}$ & $0.0 \mathrm{a}$ & $14.9 \mathrm{a}$ & $4.64 \mathrm{a}$ \\
\hline Glyphosate/dicamba & 450 & POST 1 & $0.0 \mathrm{a}$ & $0.0 \mathrm{a}$ & $0.0 \mathrm{a}$ & $0.0 \mathrm{a}$ & $0.0 \mathrm{a}$ & $15.2 \mathrm{a}$ & $4.47 \mathrm{ab}$ \\
\hline Glyphosate/dicamba & 900 & POST 1 & $0.3 \mathrm{ab}$ & $0.3 \mathrm{ab}$ & $1.4 \mathrm{abc}$ & $0.0 \mathrm{a}$ & $0.0 \mathrm{a}$ & $14.9 \mathrm{a}$ & $4.55 \mathrm{ab}$ \\
\hline Glyphosate/dicamba & 1350 & POST 1 & $1.8 \mathrm{c}$ & $1.6 \mathrm{ab}$ & $3.6 \mathrm{bc}$ & $0.4 \mathrm{ab}$ & $0.0 \mathrm{a}$ & $14.8 \mathrm{a}$ & $4.36 \mathrm{~b}$ \\
\hline Glyphosate/dicamba & 1800 & POST1 & $3.3 \mathrm{~d}$ & $2.7 \mathrm{~b}$ & $5.7 \mathrm{bcd}$ & $1.5 \mathrm{bc}$ & $0.0 \mathrm{a}$ & $15.1 \mathrm{a}$ & $4.52 \mathrm{ab}$ \\
\hline Glyphosate/dicamba & 3600 & POST1 & $5.8 \mathrm{f}$ & $3.0 \mathrm{~b}$ & $10.7 \mathrm{~d}$ & $4.6 \mathrm{~d}$ & $0.2 \mathrm{~b}$ & $14.8 \mathrm{a}$ & $4.47 \mathrm{ab}$ \\
\hline Glyphosate/dicamba & 450 & POST 2 & $0.3 \mathrm{ab}$ & $0.0 \mathrm{a}$ & $0.5 \mathrm{ab}$ & $0.0 \mathrm{a}$ & $0.0 \mathrm{a}$ & $15.2 \mathrm{a}$ & $4.42 \mathrm{ab}$ \\
\hline Glyphosate/dicamba & 900 & POST 2 & $1.3 \mathrm{bc}$ & $0.4 \mathrm{ab}$ & $0.7 \mathrm{ab}$ & $0.3 \mathrm{ab}$ & $0.0 \mathrm{a}$ & $15.1 \mathrm{a}$ & $4.46 \mathrm{ab}$ \\
\hline Glyphosate/dicamba & 1350 & POST 2 & $1.5 \mathrm{c}$ & $1.2 \mathrm{ab}$ & $2.0 \mathrm{abc}$ & $1.0 \mathrm{bc}$ & $0.0 \mathrm{a}$ & $14.9 \mathrm{a}$ & $4.44 \mathrm{ab}$ \\
\hline Glyphosate/dicamba & 1800 & POST 2 & $2.3 \mathrm{~cd}$ & $2.2 \mathrm{~b}$ & $3.7 \mathrm{bc}$ & $2.2 \mathrm{c}$ & $0.0 \mathrm{a}$ & $14.7 \mathrm{a}$ & $4.50 \mathrm{ab}$ \\
\hline Glyphosate/dicamba & 3600 & POST 2 & $4.5 \mathrm{e}$ & $3.4 \mathrm{~b}$ & $6.9 \mathrm{~cd}$ & $5.2 \mathrm{~d}$ & $1.2 \mathrm{~b}$ & $15.0 \mathrm{a}$ & $4.36 \mathrm{~b}$ \\
\hline
\end{tabular}

abbreviations: DAA, days after application; DAB, days after B application; POST, postemergence. 
900, 1350, 1800 and $3600 \mathrm{~g} \cdot \mathrm{ae} \cdot \mathrm{ha}^{-1}$ to V2/V3 DR soybean caused $0 \%, 0.3 \%, 1.6 \%$, $2.7 \%$ and $3.0 \%$ growth response, respectively (Table 1 ). These responses were transient with no growth response observed at $7 \mathrm{DAA}, 2 \mathrm{WAB}, 4 \mathrm{WAB}, 8 \mathrm{WAB}$, and late Sept. (R8) in DR soybean (data are not shown).

There was generally no difference in growth response between the two application timings (V2/V3 vs V4/V5). At 1 DAA, glyphosate/dicamba applied at 450, $900,1350,1800$ and $3600 \mathrm{~g} \cdot \mathrm{ae} \cdot \mathrm{ha}^{-1}$ to DR soybean at V4/V5 growth stage caused $0.3,1.3,1.5,2.3$ and $4.5 \%$ growth response, respectively (Table 1). At 3 DAA, glyphosate/dicamba applied at 450, 900, 1350, 1800 and $3600 \mathrm{~g} \cdot \mathrm{ae} \cdot \mathrm{ha}^{-1}$ to DR soybean at V4/V5 growth stage caused 0.0, 0.4, 1.2, 2.2 and 3.4\% growth response, respectively. The growth response was transient with no symptoms observed at $7 \mathrm{DAA}, 2 \mathrm{WAB}, 4 \mathrm{WAB}, 8 \mathrm{WAB}$, and late Sept. (R8) in DR soybean (data are not shown).

\subsection{Soybean Injury (Speckled Chlorosis and Necrosis and Leaf Distortion)}

Soybean injury followed a similar pattern as growth response. Glyphosate/ dicamba applied at 450, 900, 1350, 1800 and $3600 \mathrm{~g} \cdot \mathrm{ae} \cdot \mathrm{ha}^{-1}$ to DR soybean at the V2/V3 growth stage caused $0.0 \%, 1.4 \%, 3.6 \%, 5.7 \%$ and $10.7 \%$ injury at 3 DAA; $0.0 \%, 0.0 \%, 0.4 \%, 1.5 \%$ and $4.6 \%$ injury at $7 \mathrm{DAA}$; and $0.0 \%, 0.0 \%, 0.0 \%, 0.0 \%$ and $0.2 \%$ injury at $14 \mathrm{DAB}$, respectively. The injury was transient with no injury observed at $4 \mathrm{WAB}, 8 \mathrm{WAB}$, and late Sept. (R8) in DR soybean (data are not shown).

There was generally no difference in soybean injury between the two application timings (V2/V3 vs V4/V5). Glyphosate/dicamba applied at 450, 900, 1350, 1800 and $3600 \mathrm{~g} \cdot \mathrm{ae} \cdot \mathrm{ha}^{-1}$ to DR soybean at V4/V5 growth stage caused $0.5 \%$, $0.7 \%, 2.0 \%, 3.7 \%$ and $6.9 \%$ injury at 3 DAA; $0.0 \%, 0.3 \%, 1.0 \%, 2.2 \%$ and $5.2 \%$ injury at $7 \mathrm{DAA}$; and $0.0 \%, 0.0 \%, 0.0 \%, 0.0 \%$ and $1.2 \%$ injury at $14 \mathrm{DAB}$, respectively (Table 1 ). The injury was transient with no injury observed at $4 \mathrm{WAB}, 8$ WAB, and late Sept. (R8) in DR soybean (data are not shown).

In contrast, other studies have found $20 \%$ to $89 \%$ injury when non-DR soybean was exposed to dicamba applied at 4.4 to $280 \mathrm{~g} \cdot \mathrm{ae} \cdot \mathrm{ha}^{-1}$ at the V2/V3 growth stage [15]. Another study reported $8 \%$ to $21 \%$ injury when non-DR soybean was exposed to dicamba applied at only $3 \mathrm{~g} \cdot \mathrm{ae} \cdot \mathrm{ha}^{-1}$ at the V2/V3 growth stage [7]. Anderson et al. [16] reported 40 and $80 \%$ injury in non-DR soybean with dicamba applied at 5.6 and $56 \mathrm{~g} \cdot \mathrm{ae} \cdot \mathrm{ha}^{-1}$ at the V2/V3 trifoliate growth stage.

\subsection{Soybean Maturity and Yield}

Glyphosate/dicamba applied at 450, 900, 1350, 1800 and $3600 \mathrm{~g} \cdot \mathrm{ae} \cdot \mathrm{ha}^{-1}$ to $\mathrm{DR}$ soybean at V2/V3 or V4/V5 growth stage had no impact on crop maturity as indicated by seed moisture content at harvest (Table 1 ). There was no difference in soybean yield among the rates of glyphosate/dicamba $(450,900,1350,1800$ and $3600 \mathrm{~g} \cdot \mathrm{ae} \cdot \mathrm{ha}^{-1}$ ) applied at the V2/V3 and V4/V5 growth stages. Interestingly, DR soybean yield was reduced $6 \%$ compared to the weed-free control with gly- 
phosate/dicamba applied at $1350 \mathrm{~g} \cdot a \mathrm{a} \cdot \mathrm{ha}^{-1}$ (V2/V3) and $3600 \mathrm{~g} \cdot \mathrm{ae} \cdot \mathrm{ha}^{-1}$ (V4/V5) (Table 1). This observation will have to be confirmed in future studies. There was generally no difference in soybean seed yield between the two application timings (V2/V3 vs V4/V5). In other studies, seed yield loss of $4 \%$ and $10 \%$ have been reported with dicamba applied at 4.4 and $17.5 \mathrm{~g} \cdot \mathrm{ae}^{-h^{-1}}{ }^{-1}$ at the V2/V3 growth stage in non-DR soybean [15]. Another study reported $8 \%$ seed yield reduction when non-DR soybean was exposed to dicamba applied at $11 \mathrm{~g} \cdot \mathrm{ae}_{\mathrm{h}} \mathrm{ha}^{-1}$ at the V2/V3 growth stage [17]. Seed yield losses were as much as 34 and $83 \%$ when non-DR soybean was exposed to 5.6 and $56 \mathrm{~g} \cdot \mathrm{ae} \cdot \mathrm{ha}^{-1}$ of dicamba applied at the V2/V3 growth stage, respectively [7]. Other studies have also shown soybean seed yield losses of $18 \%$ with $1 \%$ dicamba tankmix contamination in non-DR soybean [15].

\section{Conclusion}

Results from this study showed that glyphosate/dicamba at 450, 900, 1350, 1800 and $3600 \mathrm{~g} \cdot \mathrm{ae} \cdot \mathrm{ha}^{-1}$ can cause up to a $6 \%$ growth response and $11 \%$ injury in DR soybean. This response was transient with no growth response or injury symptoms observed beyond $14 \mathrm{DAB}$. There was no impact of glyphosate/dicamba at various rates evaluated on maturity, but seed yield was reduced as much as $6 \%$ compared to the weed-free control. There were generally no differences in responses observed between the two application timings (V2/V3 vs V4/V5) evaluated. Based on these results, glyphosate/dicamba at the labelled rates can be safely applied at the V2/V3 and V4/V5 growth stage in DR soybean. However, care is needed to avoid spray overlaps as the $2 \times$ rate can result in significant DR soybean injury and yield loss.

\section{Fund}

Funding for this project was provided in part by the Grain Farmers of Ontario (GFO) and the Growing forward 2 (GF2) program of the Agricultural Adaptation Council.

\section{Conflicts of Interest}

The authors declare no conflicts of interest regarding the publication of this paper.

\section{References}

[1] Ontario Ministry of Agriculture, Food and Rural Affairs (2019) Area, Yield, Production and Farm Value of Specified Field Crops (Imperial and Metric Units). Ontario of Agriculture, Food and Rural Affairs.

http://www.omafra.gov.on.ca/english/stats/crops/index.html

[2] Byker, H.P., Soltani, N., Robinson, D.E., Tardif, F.J., Lawton, M.B. and Sikkema, P.H. (2013) Control of Glyphosate-Resistant Canada Fleabane (Conyza canadensis (L.) Cronq.) Preplant Herbicide Tankmixes in Soybean (Glycine max (L). Merr.). Canadian Journal of Plant Science, 93, 659-667. 
https://doi.org/10.4141/cjps2012-320

[3] Ontario Ministry of Agriculture, Food and Rural Affairs (2018) Guide to Weed Control. Publication 75. OMAF, Toronto, $355 \mathrm{p}$.

[4] Shaner, D.L. (2014) Herbicide Handbook. 10th Edition, Weed Science Society of America, Champaign, 513 p.

[5] Heap, I (2019) The International Survey of Herbicide Resistant Weeds. http://www.weedscience.org

[6] Johnson, W.G., Young, B., Matthews, J., Marquardt, P., Slack, C., Bradley, K., York, A., Culpepper, S., Hager, A., Al-Khatib, K., Steckel, L., Moechnig, M., Loux, M., Bernards, M. and Smeda, R. (2010) Weed Control in Dicamba-Resistant Soybeans. http://www.plantmanagementnetwork.org https://doi.org/10.1094/CM-2010-0920-01-RS

[7] Johnson, V.A., Fisher, L.R., Jordan, D.L., Edmisten, K.E., Stewart, A.M. and York, A.C. (2012) Cotton, Peanut, and Soybean Response to Sublethal Rates of Dicamba, Glufosinate, and 2,4-D. Weed Technology, 26, 195-206.

https://doi.org/10.1614/WT-D-11-00054.1

[8] Spaunhorst, D.J. and Bradley, K.W. (2013) Influence of Dicamba and Dicamba plus Glyphosate Combinations on the Control of Glyphosate-Resistant Waterhemp (Amaranthus rudis). Weed Technology, 27, 675-681. https://doi.org/10.1614/WT-D-13-00081.1

[9] Spaunhorst, D.J., Seifert-Higgins, S. and Bradley, K.W. (2014) Glyphosate-Resistant Giant Ragweed (Ambrosia trifida) and Waterhemp (Amaranthus rudis) Management in Dicamba-Resistant Soybean (Glycine max). Weed Technology, 28, 131-141. https://doi.org/10.1614/WT-D-13-00091.1

[10] Vink, J.P., Soltani, N., Robinson, D.E., Tardif, F.J., Lawton, M.B. and Sikkema, P.H. (2012) Glyphosate-Resistant Giant Ragweed (Ambrosia trifida) Control in Dicamba-Resistant Soybean. Weed Technology, 26, 422-428. https://doi.org/10.1614/WT-D-11-00184.1

[11] Byker, H.P. (2013) Glyphosate-Resistant Canada Fleabane (Conyza canadensis (L.) Cronq.) in Ontario: Distribution and Control in Soybean (Glycine max (L). Merr.). University of Guelph, Guelph. https://atrium.lib.uoguelph.ca/xmlui/bitstream https://doi.org/10.4141/cjps2012-320

[12] Jones, G.T., Norsworthy, J.K., Barber, T., Gbur, E. and Kruger, G.R. (2019) Off-Target Movement of DGA and BAPMA Dicamba to Sensitive Soybean. Weed Technology, 33, 51-65. https://doi.org/10.1017/wet.2018.121

[13] Huang, Y., Lin, Y., Reddy, K.N. and Zhang, J. (2016) In-Situ Plant Hyperspectral Sensing for Early Detection of Soybean Injury from Dicamba. Biosystems Engineering, 149, 51-59. https://doi.org/10.1016/j.biosystemseng.2016.06.013

[14] Zhang, J., Huang, Y., Reddy, K.N. and Wang, B. (2019) Assessing Crop Damage from Dicamba on Non-Dicamba-Tolerant Soybean by Hyperspectral Imaging through Machine Learning. Pest Management Science. https://doi.org/10.1002/ps.5448

[15] Griffin, J.L., Bauerle, M.J., Stephenson III, D.O., Miller, D.K. and Boudreaux, M. (2013) Soybean Response to Dicamba Applied at Vegetative and Reproductive Growth Stages. Weed Technology, 27, 696-703. https://doi.org/10.1614/WT-D-13-00084.1

[16] Andersen, S.M., Clay, S.A., Wrage, L.J. and Matthees, D. (2004) Soybean Foliage Residues of Dicamba and 2,4-D and Correlations to Application Rates and Yield. 
N. Soltani et al.

Agronomy Journal, 96, 750-760. https://doi.org/10.2134/agronj2004.0750

[17] Auch, D.E. and Arnold, W.E. (1978) Dicamba Use and Injury to Soybeans (Glycine max) in South Dakota. Weed Science, 26, 471-475.

https://doi.org/10.1017/S0043174500050347 